\title{
Mandatory Immunization Policy by Rulers from Islamic Perspective
}

\author{
Ahmad Faidhi M.Z. ${ }^{1}$, Basri, I. ${ }^{2}$
}

${ }^{1}$ Universiti Islam Malaysia, Cyberjaya, Malaysia / Hospital Angkatan Tentera Tuanku Mizan, Kuala Lumpur, Malaysia;

${ }^{2}$ Universiti Islam Malaysia, Cyberjaya, Malaysia / Faculty of Islamic Contemporary Studies, Universiti Sultan Zainal Abidin, Terengganu, Malaysia

\begin{abstract}
Introduction: Islam views life as a sacred entity that sanctioned utmost protection according to the Objective of Syariah (Maqasid Syariah). Immunization has historically and epidemiologically proven to safeguard human life (hifzun nafs) from life threatening communicable disease. Recent development witnesses increasing vaccine refusal and hesitancy (VHR) which would jeopardize global immunization effort and its desired noble outcome. Hence there is proposal from various party for the Ministry of Health to enact a mandatory immunization policy. This study aims to analyze mandatory immunization policy by governing rulers from Islamic perspective.

Methods: This is a qualitative study. Document analysis from Islamic jurisprudence (fiqh) references including some literature on Maqasid Syariah, Qawaid Fiqhiyyah and Siayah Syariah perspective. Interviews with expert from both Islamic scholars and clinicians was conducted.
\end{abstract}

Results: The study recognizes that mass immunization to achieve herd immunity is considered communal obligation (fardhu kifayah). Islamic legal principles such as consideration of public interest (Masalih Mursalah) and blocking evil means (Sadd-az-Zaraie) as well as legal maxim (Qawaid Fiqhiyyah) to prevent harm (darar) would serve as basis to support this policy. The contemporary Islamic jurisprudence approach such as weighting preference (fiqh muwazanat) and considering implications (figh ma'alat) may justify the ruler's action to enact mandatory immunization as in accordance with the principle of Siyasah Syariyyah that the rulers must safeguard the wellbeing of whole community.

Conclusion: This study may serve as preliminary paper and reference to respective authority and policy makers on Islamic perspective towards mandatory immunization policy. 